\title{
Stratification and Role of the Elite Muslim Women in the State of Awadh, 1742-1857
}

\begin{abstract}
By Naumana Kiran*
This paper focuses on stratification and role of the elite Muslim women in the State of Awadh during the second-half of the eighteenth, and first-half of nineteenth century India. It evaluates the categorization of women associated with the court and the division of political and domestic power among them. It also seeks their economic resources and their contribution in fields of art and architecture. The study finds that the first category of royal women of Awadh, including queen mothers and chief wives, enjoyed a powerful position in the state-matters unlike many other states of the time in India. Besides a high cadre of royal ladies, three more cadres of royal women existed in Awadh's court with multiple ratios of power and economic resources. Elite women's input and backing to various genres of art, language and culture resulted in growth of Urdu poetry, prose, drama and music in addition to religious architecture. The paper has been produced on the basis of primary and secondary sources. It includes the historical accounts, written by contemporary historians as well as cultural writings, produced by poets and literary figures of the time, besides letters and other writings of the rulers of Awadh. The writings produced by the British travelers, used in this paper, have further provided an insightful picture and a distinctive perspective.
\end{abstract}

\section{Introduction}

The study of Muslim women of Awadh, like women of all other areas of India during the $18^{\text {th }}$ and $19^{\text {th }}$ centuries, is a marginalized theme of study in historiography of India. It never meant that women were inactive or not performing well on national, state or other levels. They had been doing an excellent job in many echelons and the need is to investigate their services and role in politics and other fields of life. This paper is an attempt to find out stratification of Awadh's Muslim women associated with the court specifically. It seeks to discover what role they were playing in politics in the state of Awadh: directly or indirectly? What was their contribution in the fields of art, architecture and literature, and what role had they played in the War of Independence against the British East India Company (BEIC)? This paper negates the idea of Knighten, author of The Eastern King, that the royal ladies regarded men as a superior order of being, listened to their views as the child listen to those of his parents, adopted their views, and embraced their opinions with unhesitating confidence that bespeaks child-like simplicity and implicit faith. ${ }^{1}$ This paper finds that all Royal women of Awadh were not dependent on the males, and many of them were not

*Professor, University of the Punjab, Pakistan.

1. Muhammad Taqi Ahmad, Tarikh Badshah Begam (Allahabad: K. Mitra, 1938), iii. 
only independent in their own decisions, but also guided the male counterparts of the royal family; even the Kings and Nawabs. In some cases, they proved to be more sensible and prudent than the Nawabs and Kings. There were many highspirited royal ladies, who were exceedingly ambitious and self-willed including Sadr un Nisa Begum, Bahu Begum, Badshah Begum, Kishwar Sultana and Hazarat Mahal, and others. ${ }^{2}$ The elite women of Awadh were equally literate and had interest in cultural activities.

Awadh, known as Avadh, Oude or Oudh, is located in the north-eastern part of Uttar Pradesh, which is the heart of the Indo-Gangetic plain. The origin of its name is traced back to Ayodhya, ${ }^{3}$ the capital of the ancient kingdom of Kosala. ${ }^{4}$ Muslims occupied the region in the twelfth century and it became part of the Mughal Empire in the $16^{\text {th }}$ century A.D. The majority of the population of the region was Hindu and Muslims always remained in the minority, ${ }^{5}$ even until the annexation of the state by BEIC. The state of Awadh was established by Mir Muhammad Amin, an Iranian Shia. He was appointed as governor of Awadh on 15 September 1722 by the Mughal emperor, where he established an independent dynasty gradually, under Mughal sovereignty and adopted the title of Sada'at Khan Bahadur. He established the capital of his state in Faizabad, ${ }^{6}$ but later the capital was shifted to Lucknow ${ }^{7}$ in 1775 . Nawab Sada'at was succeeded by his nephew and son-in-law Mirza Muhammad Muqeem, entitled as Safdar Jang, in 1740. Shuja-ad-Daulah succeeded Safdar Jang in 1754. Asif ud Daula took over in January 1775 and ruled until September $1797 .{ }^{8}$ Wazir Ali could rule for only a year and was replaced by Sa'adat Ali Khan, who was recognized by the BEIC also. ${ }^{9}$

Early Nawabs of the state were capable rulers and resisted against BEIC. However, the last five rulers of the Dynasty including Ghazi al-Din Hydar (r. 1814-1827), Naseer al-Din Hydar (r. 1827-1837), Mohammad Ali Shah (1837-1842),

2. The detailed discussion on all these women will follow at appropriate places in the paper.

3. Kosala was an ancient kingdom, covering area of the modern state of Awadh, in the late Vedic period.

4. Maulana Mohammad Najam ul Ghani, Tarikh-i-Oudh Vol. 1 (Udipur: np, 1910), 33-34; Munshi Ram Sahai, Ahsan-ut Tawareekh: Tarikh-i- Subah Oudh (np: Munshi Puran Chand, n.d.), 7.

5. Veena Talwar Oldenburg, The Making of Colonial Lucknow (Delhi: OUP, 1989), 263; Ashirbadi Lal Srivastava, The First Two Nawabs of Oudh (Lucknow: The Upper India Publishing House Ltd, 1933), 263.

6. Faizabad, known as Fyzabad during British colonial rule, was the first capital of the state of Awadh. It is situated on river bank of ghaghra (also known as Saryu river).

7. It is currently capital of the Indian State of Uttar Pradesh. It is located near Gomti river.

8. Maulana Mohammad Najam ul Ghani, Tarikh-i-Oudh (Udipur: np, 1910), 494.

9. W. H. Sleeman, Rambles and Recollections of an Indian Official (Karachi: OUP, 1973 reprint), 473-474. 
Amjad Ali Shah (1842-1847) and Wajid Ali Shah (r. 1847-1856) were benevolent and humane, but were powerless due to increasing economic and political encroachment ${ }^{\prime 10}$ of the Company's officials. Finally, the Company annexed the State in 1856, whereas Wajid Ali Shah, the last ruler, was retired with a stipend. He lived in Calcutta and spent the last many years of his life there. ${ }^{11}$ During the War of Independence of 1857, freedom fighters appointed one of the sons of Wajid Ali Shah, only 10 years old, under supervision of Hazrat Mahal, as King of Awadh and started a rebellion. That situation continued for almost seven months. The British forces diverted back to Awadh in 1858 and defeated the disorganized, disunited force of Awadh within two to three days. ${ }^{12}$

\section{Stratification of Women Affiliated with the Court}

The influential women, affiliated with the Court and the royal family, can be categorized into four sections. The most dynamic and vibrant section consisted of the Queen-mother, grand-mother and the Chief Wives of the Kings. This group was in a position of directly interfering with the state-affairs and ruled both directly and indirectly. Sadar un Nisa Begum, Bahu Begum, Badshah Begum, Kishwar Sultana and Hazarat Mahal ${ }^{13}$ are a few examples of the women making up this section.

The second category of such women consisted of the most favourite courtesans of not only Kings but also of the prime Minister or Ministers, in some cases. This group's emergence in the state of Awadh was observed since the days of Shuja ud Daula, and in many instances, they had influenced the state's affairs indirectly. Jalalu, Surfraz Mahal and Beeba Jan ${ }^{14}$ are a few representatives of this segment of women.

There was another less powerful but active or radical category of royal women; the sisters of the kings or some daughters of the Nawabs. They had altogether negated the institution of marriage and preferred to spend lives alone. They were prone to be dependent on males and wanted to live as they liked. They adopted unusual methods to convince the Kings to increase their monthly stipends. Daughters of Nawab Shuja ud Daula are major representatives of this section of royal women. They initiated women activism in the society of Awadh

10. Nawab Husayn Ali Khan, "Tarikh-i-Husayniyyah," in Perspectives on Mughal India: Rulers, Historians, Ulama and Sufis, edited by Sajida Sultana Alvi (Karachi: OUP, 2012), 78.

11. Mohammad Baqir (Ed.), Tarikh-i-Mumtaz (Lahore: Urdu Markaz, n.d.), 3-4. He wrote many letters to his wife from there in which he had written about his hardships.

12. Abdul Haleem Sharar, Hindustan Mein Mashriqi Tamadun Ka Akhri Namoona (Lahore: Merkantil Press, n.d.), 58-60.

13. The detailed account of all these women has been given in the following pages.

14. The details of all these women have been given in the following pages. 
for the rights of women. This section of royal women included less influential or common wives of the Nawabs or Kings also.

The fourth category of women whose rise was observed only during the last years of the state was of employees of the royal household, especially of kitchen and the affiliated departments. Some of them were Barati Khanum, Jugna Khanum and Naurozi Begum.

\section{Politics and the Muslim Women}

Generally, the perception had been developed by orientalists that Muslim women of the Indo-Pak sub-continent were confined to four boundaries and restricted to purdah which was a hindrance to the way of their political and social activism. But the royal women of Awadh in the $18^{\text {th }}$ and $19^{\text {th }}$ centuries, representing multiple groups had proved this kind of assessment wrong. All four categories of royal women of Awadh were performing active, and even more dynamic role than males, but with a diverse ratio of power and wisdom. Most of the royal women observed purdah, but it was their strength, not weakness.

\section{Prominent Begums of Awadh}

The most dominant part in politics of the State was played by powerful begums of the royal family. Nawab Begum Sadar un Nisa - the imperious daughter of one Nawab (Sada'at Khan Bahadur), wife of another (Safdar Jang), mother of the third (Nawab Shuja-ad-Daulah) and grandmother of the fourth (Asif ud Daula) - was the first conspicuous lady of the Muslim royal family of Awadh. She was talented, wise, illustrious, chaste and a virtuous lady. ${ }^{15}$ She was the single wife of Safdar Jang, the second Nawab of Awadh, unlike common custom of that period among the ruling families. Safdar Jang had great affection for her. ${ }^{16}$ Begum Sadar un Nisa accompanied her husband to deal with the rebellious faction when horror and disorder spread in Awadh after the death of Sada'at Khan Bahadur, ${ }^{17}$ the first Nawab of the State. Being the daughter of the first Nawab, her companionship to her husband in dealing with the opponents proved to be fruitful, and peace was restored with the great haste. She encouraged, and even counseled, Safdar Jang to deal with the issues in that time of crisis. ${ }^{18}$ In September 1750, Safdar Jang faced a defeat against Pathans. ${ }^{19}$ The

15. Ashirbadi Lal Srivastava, The First Two Nawabs of Oudh (Lucknow: The Upper India Publishing House ltd, 1933), 83.

16. Ibid, 253.

17. Sa'adat Khan did not have any son so the state was inherited to his eldest son in law.

18. Tarikh-i-Farah Bakhsh cited in Srivastva, The First Two Nawabs of Awadh, 93. 
news spread like wild fire that Safdar Jang had been killed while fighting. The conspirators raised Imtiaz ud Daula, a courtier, to be seated on the throne of Awadh. Begum Sadar un Nisa kept her senses in control and raised an army of 10,000 soldiers; she appointed her son as commander of the forces and supervised the force to defend the city of Faizabad. The opposition forces were muzzled for the time being which waited for the confirmation of the news of Safdar Jang's death. ${ }^{20}$ Safdar Jang returned back safely after few days. Begum Sadar un Nisa's wisdom and quick action saved the state from bloodshed and rebellion.

Safdar Jang was again in trouble and had to fight in the second Afghan War. He was facing finance problems. At that time, his wife came up with the whole of her property including Rs. 1,10,000 and 4,000 gold coins. With that, he recollected himself, gathered his forces and successfully fought the war. ${ }^{21}$ Begum Sadar un Nisa remained a source of not only encouragement and support, but also had come up with the material help and accompanied her husband physically and practically in restoring order, dealing with the enemies and in successfully catering with the rebellious faction in case of absence of the Nawab from the capital. These traits present her as equal partner or key player of state-making and building.

Begum Sadar un Nisa remained effective and helpful during Shuja ud Daula's period also. She helped her son in many difficult times. On the issue of a Rajput girl who was kidnapped by the orders of Shuja ud Daula, the third ruler of Awadh and son of Sadr un Nisa; a misunderstanding had been created between Hindu and Muslim nobility. Some of the King's relatives including Muhammad Quli khan and Mughal courtiers wanted to dismiss Shuja ud Daula. At that occasion, Begum Sadar un Nisa called Ram Narain, a closest Rajput associate of Safdar Jang and reminded him of all the favours done by Nawab Safdar Jang towards him. She solicited him to be polite and patient towards Shuja ud Daula. She advised him not to overreact on a minor issue of a common Hindu family and to instead be supportive to Shuja ud Daula. As a result, he requested the Queen-mother to call Ismail Baig and sardars (leaders) of Mughals to issue the same advice. She called, talked to them and convinced them. They deferred their campaign of Shuja ud Daula's dismissal, only then. ${ }^{22}$ On the death-bed of Shuja ud Doula, his mother came and issued three pieces of advice to him on the basis of her long experience. She emphasized that he should release Pathans and fix stipends for their livelihood; to release stipend of inhabitants of occupied areas;

19. Pathans are an ethnic group, mostly settled in North Western region of Pakistan but are scattered in the whole of Indo-Pak Subcontinent region. They are popular since ages as fierce fighters.

20. Ibid, 163.

21. Ibid, 175 .

22. Syed Kamal ud Din Hyder, Swanehayat-Salateen Awadh (Lucknow: Valashkor, 1879), 51-52. 
and to give reasonable freedom to the people of Faizabad in their daily movement. However, he did not listen to the advice of the Queen-mother.

Begums of Awadh had decision-making power in their hands with regard to the appointment of the next Nawab, after the death of the one. Begum Sadar un Nisa had to take Bahu Begum, the chief wife of Shuja ud Daula in her confidence, while appointing the next Nawab after death of Shuja ud Daula. She advised Bahu Begum at the time of Asif ud Daula's accession that Asif ud Daula was not a serious administrator and was involved in deleterious activities, so he should be appointed on the throne just as a formality and that actual administration should be given to Saadat Ali khan, another son of Shuja ud Daula. Bahu Begum refused, while saying that she had only one son, whether good or bad, she would not be in favour of giving power to any other son of Shujah. Grandmother was highly disappointed, but agreed..$^{23}$

The grandmother, on the second day of appointment of Asif ud Daula, imparted some advice to him. Begum Sadar un Nisa said while advising the new Nawab, that he should work with seasoned administrators and military generals including Eluch Khan, Raja Soorat Singh and Raja Butar Chund, who had been trusted fellows of his father and grandfather. She asked him to work according to the advice of these ministers, but Asif ud Daula was not ready to listen to his grandmother, so sidelined the above ministers. ${ }^{24}$ Grandmother continued her efforts to keep the state of Awadh on track through her advice to Asif ud Daula in the future also.

In the period of Asif ud Daula, another royal lady besides Sadar un Nisa emerged as a powerful figure in the court. She was Bahu Begum (Aliya Begum), mother of Asif ud Daula, sister of Najam ud Daula, ${ }^{25}$ daughter of Motam ud Daula (governor of Gujrat) and foster child of King Muhammad Shah. She was Chief wife of Shuja ud Daula and was given high respect and esteem by royal family of Awadh due to her respectable lineage. ${ }^{26}$ Bahu Begum was given the charge of overseeing the whole treasury during the life of Shuja ud Daula because she had proved herself as the most trustworthy individual. She had given the whole of her wealth to her husband at the time of his treaty with the British in 1764. Besides government treasury, she was owner of a lot of Jagirs (land grants or estates) and utilized profit, earned from her agricultural land, for her personal benefits. She wanted to rule the state of Awadh through her son, and practically behaved like a ruler during the initial months, but Asif ud Daula resisted. ${ }^{27}$ Asif ud Daula was extravagant and started teasing his mother only a few days after

23. Najmul Ghani, Tarikh-i-Oudh (Udipur: np, 1910), 6-7.

24. Ibid, 18.

25. He was the Nawab of Bengal, Bihar and Orissa from 1765 to 1766 and was the second son of Mir Jafar.

26. Najmul Ghani, Tarikh-i-Oudh, 30-31.

27. Karen Chancey, "Rethinking the Reign of Asaf ud Daula, Nawab of Awadh, 1775-1797," Journal of Asian History 41, no. 1 (2007): 15. 
his father's death for money again and again. He wanted to go for entertainment with a big troop. His mother had to give him money, very reluctantly, in two installments i.e. Rs. 60,000 and Rs. 40,000. That was the start of the rift between the mother and the son. She advised him not to be too profligate. ${ }^{28}$ Shuja ud Daula had left the whole property to his mother and wife, not to the son, before his death. ${ }^{29}$ The conflict between the Begums, especially the mother and the son, had reached to such a level that he was reluctant to live in the same city with his mother. He finally left Faizabad and settled in Lucknow, while upgrading its status as the capital. ${ }^{30}$

Bahu Begum had appointed her forces in the territory under her control and replied all moves of the King Asif ud Daula wisely and tactfully. On listening to the rumor that Asif ud Daula wanted to annex her jagirs, she wrote a letter to the British Resident and asked him for help, but he did not take any action at that time. ${ }^{31}$ A small force of Nawab interfered in Begum's villages but that was dealt with dexterously by the forces of the Begum. Unfortunately, the jagirs of Bahu Begum had been annexed by Asif ud Daula in 1196 hijra. He himself came to Faizabad with his forces. Bahu Begum shifted to the palace of her mother-in-law, Sadar un Nisa Begum. On second stage, the jagirs of grandmother were also occupied by the state. ${ }^{32}$ Bahu Begum wrote a letter to his son and another to the British authorities, abashing his son on his very cruel act against his grandmother and her dependents. Finally, the jagirs were restored with the order of the British resident as that act of Asif ud Daula had been rejected by the British authorities in London. ${ }^{33}$ Later, Bahu Begum ruled in her vast jagir as a powerful ruler, without interference from the Nawab of Awadh.

Wazir Ali Khan, the disputed son of Asif ud Daula, ascended to the throne with the approval of Bahu Begum and the Company after his death, but controversy started and a wide-spread opposition was generated due to his behavior, aggressive policies and low birth rates. ${ }^{34}$ The British authorities also developed robust feelings against Wazir Ali Khan because he was highly antiBritish in his behavior and policies. Begum supported him just to have a hand in the administration of the state. She, on observing large scale opposition,

28. Najmul Ghani, Tarikh-i-Oudh, 29-30.

29. Julie Stone Peters, "Theatricality, Legalism and the Scenography of Sufferings: The Trial of Warren Hastings and Richard Brinsley Sheridan Pizarro," Law and Literature 18, no. 1 (2006): 21.

30. Abdul Haleem Sharar, The Lucknow: The Last Phase of an Oriental Culture (New Delhi: OUP, 2001); The Omnibus Addition, 45.

31. Najmul Ghani, Tarikh-i-Oudh, 170-171.

32. Ibid, 228.

33. Farah Bakhsh, in Najmul Ghani, Tarikh-i-Oudh, 226.

34. Michal H. Fisher, "Political Marriage Alliances at the Shi'i Courte of Awadh," Comparative Studies in Society and History 25, no. 4 (1983): 603. 
withdrew her support. ${ }^{35}$ The dismissal of Wazir Ali Khan in 1797 was the unanimous decision of the Begums as well as of the nobility. ${ }^{36}$ The Resident and Bahu Begum wanted to replace him with another son of Nawab Shuja ud Daula, and step son of Bahu Begum, Saadat Ali Khan. He was living in Banaras at that time. He was brought back from Banaras and ascended on the throne with the help of the British resident, who held darbar for a congregation ceremony. ${ }^{37}$ Bahu Begum was instrumental in the whole process of this unnatural shift of power.

Bahu Begum was on good terms with the British resident. She was such a forceful character that the British resident wrote a letter to her and asked about her opinion about Sa'adat before his nomination as the King of Awadh. She further requested that the resident restore her remaining property which was occupied by her son, Asif ud Daula. In addition to it, she requested to begin the process of paying monthly salaries to all royal ladies that was smooth, regular and on-time. ${ }^{38}$ The ownership of the big jagirs was left with Bahu Begum and Sadr un Nisa until the end of their lives. The ladies preferred to live in Faizabad. ${ }^{39}$ During Sa'adat's regime, Bahu Begum ruled in Faizabad and other areas of her jagir as a forceful and independent ruler. ${ }^{40}$ Her forces and servants interfered in the administrative and judicial matters of the state of Awadh also. Nawab met with the governor general and informed him of the situation. The governor general ordered that Begum should not interfere in the matters of the state and that administration and justice should be ensured by Sa'adat's authority with the help of the British resident. ${ }^{41}$ Bahu Begum had to agree but she did not appreciate the occasional interference of the government, and still most of the matters were handled by her employees under her supervision.

Bahu Begum died at the age of eighty six on $18^{\text {th }}$ December $1815 .{ }^{42}$ She appointed the Company as trustee of her property and through it, Ghaz iud Din, King of Awadh, was responsible to look after the affairs of her jagir. The administration of a lot of her factories, lands and business, etc. was in the hands of Bakhtawar Singh Brahmin, assistant of the resident and Munshi Hyder, and

35. Purnendu Basu, Oudh and the East India Company, 1785-1801 (Lucknow: Maxwell Company, 1943), 163.

36. Nawab Husayn Ali Khan, Tarikh-i-Husayniyya cited in Sajida Sultana Alvi, Perspectives on Mughal India: Rulers, Historians, Ulema and Sufis (Karachi: OUP, 2012), 77.

37. Sharar, Lucknow: the Last Phase, 49. For further details on this episode, see details in Sleeman, Chapter 4, volume II.

38. Najmul Ghani, Tarikh-i-Oudh, 5.

39. Vil. III, 125.

40. Chancey, "Rethinking the Reign of Asaf ud Daula...," 15.

41. Hyder, Swanehayat-Salateen, 159.

42. S. N. Singh, The Kingdom of Awadh: Its History, Polity and Administration (New Delhi: Mittal Publications, 2003), 68. 
trusted employee of the Begum. ${ }^{43}$ Later, the profit of Bahu Begum's property was paid directly to the Company's treasury. ${ }^{44}$

With the death of Bahu Begum, another royal woman, Badshah Begum, the chief consort/wife of King Ghazi ud Din Hyder, emerged as a strong character. She was daughter of Munajjamul Mulk, a Rizvi Syed. The family migrated from Mash'hed and enjoyed high social status. ${ }^{45}$ She, an educated and learned lady, had a very good training in theory and practice of science of astronomy. Ghazi ud Din Hyder, with the accession on the throne, entitled Badshah Begum as Bilkis us Sitwat. She was entrusted with the full powers inside the palace and to administer her newly granted jagir, pargana of Salan. She presented a nazar (gift) of Rs. 25000 to Ghazi ud Din in the coronation ceremony. ${ }^{46}$ She was owner of a big jagir and recruited a number of soldiers and appointed them on her jagir and other areas under her authority. ${ }^{47}$ She had been described as an 'illustrious lady" and "the most wonderful woman in the world" 48 by Capt. White, the author of The Murdered King of Oudh. Gazi ud Din Haider usually followed her advice. ${ }^{49}$

Unfortunately, conflicts developed between Ghazi ud Din and Badshah Begum due to malevolence of some ministers who disliked the influence of Begum on the king and her habit of dictation on the ministers. In Tarikh-iHusayniyyah, it is mentioned that Aqa Meer was one of the ministers responsible for the unpleasant relationship between Ghazi ud Din and Badshah Begum. ${ }^{50}$ According to another tradition, Mutama ud daula, the deputy to the king, created misunderstandings between the king and his chief wife. She wanted to make a nephew of her chief maid Faiz un Nisha, Fazal Ali, as deputy or Prime Minister, in the best interest of the state. Misunderstandings were settled for the time being with the involvement of the British resident. The King revived relations with his wife. ${ }^{51}$

Badshah Begum remained equally powerful during her son, Naseer ud Din Hyder's ruling period. ${ }^{52} \mathrm{He}$ listened and followed the orders and advice of the

43. Najmul Ghani, Tarikh-i-Oudh, 129-130.

44. Robert Wilberforce, Dacoity in Excelsis or the Spoliation of Oude by the East India Company: Faithfully Recounted with Notes and Documentary Illustrations (London: J. R. Taylor, 1954), 63.

45. Taqi, Tarikh-i-Padshah Begam, 3-4.

46. Michael H. Fisher, "The Imperial Coronation of 1829: Awadh, the British and the Mughal," Modern Asian Studies 19, no. 2 (1985): 264.

47. Taqi Ahmad, Tarikh-i-Padshah Begam, 20.

48. Ibid, vii.

49. Ibid, 6.

50. Nawab Hussain Ali Khan, "Tarikh-i-Husayniyyah" in Perspectives on Mughal India, 80.

51. Taqi Ahmad, Tarikh-i-Padshah Begam, 20

52. Naseer ud Din Hyder was step son of Badshah Begum but she brought up the child with extra care and love. 
Queen-mother obediently. ${ }^{53}$ However, conflicting relationships developed between both son and the queen mother. Naseer ud Din was addicted to alcohol and could not develop an interest in administrative affairs. ${ }^{54}$ The gap was filled by Badshsash Begum who was there to direct the Ministers. She, on behalf of King Naseer ud Din, issued an order that the mourning period would continue until $20^{\text {th }}$ Safer and that no celebration or marriage ceremony would be held in this period. Otherwise, the culprits would face wrath of the King. The decision was taken back with the interference of the Resident only. ${ }^{55}$ The other reason of conflict between both of them was Qudsiya Mahal, one of the wives of Naseerud-Din. Badshash Begum disliked her and did not consider her a trustworthy and faithful lady. Qudsiya, finally, committed suicide and the king blamed Badshash Begum for it. He remained under grief for many days to come. ${ }^{56}$ The conflicting relations between the mother and the son were transformed into rivalry due to the evil character of some ministers who did not want to work under the orders of the Begum. It reached its lowest ebb in April 1835 when royal forces attacked the palace of Badshash Begum. Begum and her forces resisted well and many of her male and female servants were killed while fighting. Begum and her remaining servants took refuge in imam bara (religious temple of Shias) constructed by her within the palace. Nawab Roshan-ud-Daula intervened and requested the King to let the Begum go to Almas Bagh. ${ }^{57}$ Permission was granted and Begum, along with her servants, spent one night there without food and other necessities. Later, arrangements were made for her permanent stay and her remaining things were departed there with the orders of the King. ${ }^{58}$ The sad episode had taken place due to malicious designs of selfish ministers who did not want to see power in the hands of a respectable woman. Meanwhile, in 1837, Naseer ud Din Hyder was poisoned and died.

Badshah Begum wanted appointment of her grandson, Munna Jan, as the new King. The name of Muna Jan's mother was Afzal Mahal. ${ }^{59}$ She brought Munna Jan in Barah Dari, the throne room where a congregation ceremony was taking place whereas the British resident went there with Nasir $u$ Doula Muhammad Ali Khan, son of Nawab Sa'adat Ali Khan for the said ceremony. The British Resident tried to stop Badshah Begum but she forcefully placed Munna Jan on the throne. Although the resident and his assistant presented a directive from the Governor General about Munna Jan's ineligibility to be seated as the king, yet the Begum continued with her orders. Some of her soldiers attacked the Assistant resident, also. Consequently, the Resident called its troops

53. Taqi Ahmad, Tarikh-i-Padshah Begam, 17.

54. Hyder, Sawanehayat-Salateen, 265.

55. Taqi Ahmad, Tarikh-i-Padshah Begam, 14.

56. Hyder, Sawanehayat- Salateen, 329.

57. There were houses under state's authority, which were not in good condition.

58. Hyder, Sawanehayat- Salateen, 327.

59.Taqi Ahmad, Tarikh-i-Padshah Begam, 89. 
to attack the congregation function. Some people died of gunshots. Munna Jan tried to escape but he and the Begum were arrested. At the same time, Nasir ud Daula was installed on the throne with the title of Mohammad Ali Shah. Both Badshah Begum and Munna Jan were kept in Chunnar Gargh ${ }^{60}$ with the monthly allowance of twenty four hundred from Lucknow royal treasury. ${ }^{61}$

A controversy had been created on the royal lineage of Munna Jan. The resident did not want the appointment of Munna Jan, so the British forces supported the other, whereas, Col. Sleeman, after twelve-years of the coup, supported Munna Jan's claim to be member of the royal family. He mentioned that Afzal Mahal was mother of Munna Jan. She was of humble birth and had a fair reputation among those who knew her. Badshah Begum, during the last days of her life in the prison, always declared that she had seen the birth of the boy i.e. Munna Jan. Later, she developed extraordinary affection for him. His deeds were remarkably like Naseer ud din and his facial features were also like him. ${ }^{62}$

Badshah Begum spent the last years of her life in the prison. Her active political career indicates that she was such a dynamic politician that she resisted and performed well while having conflicting relations with her husband Ghazi ud din Hyder and a son at such a time when both of them were in power. Her role was significant in the appointment of the Kings. She was the best example of resistance also, unlike many other royal figures, as she took a stand against BEIC and forcefully fought for that stand. She was stronger than many males of her time.

The next influential and active royal lady was Queen mother of Wajid Ali Shah, Janab Aliah Queen Kishwar. She was daughter of Nawab Hussain ud Din Khan or Imam ud Din. Her real name was Taj Ara and she was chief wife of King Amjad Ali Shah (ruling period 1842-1847) and mother of Wajid Ali Shah, the last ruler of the state of Awadh. It was she who finalized the terms of the last treaty between the State of Awadh and the Company. The Resident General Ottram had a meeting with Queen Kishwar at the zard palace before getting a signature on the new treaty from the King. She was astonished and requested the Resident to intercede for her son and avert the impending calamity. ${ }^{63}$ The Resident regretfully said that he did not have that kind of right. Queen mother's request of a grace period for the improvement of the administration was also rejected by the Resident. The meeting with the mother was followed by the meeting with the

60. They were most probably imprisoned in the historical Chunnar fort, which is currently located in Mirzapur District, UP, India. It had previously remained in the possession of Safdar Jang also. It was the same fort where Ranni Jindan, mother of Ranjeet Singh was imprisoned later.

61. Ibid, 80-89.

62. Sleeman, Rambles and Recollections of an Indian Official Karachi: OUP, 1973 reprint), 199.

63. G. D. Bhatnagar, Awadh Under Wajid Ali Shah (Varanasi: Bharatiya Vidya Prakashan, 1965), 146. 
King on 4 February 1856. The King was informed formally who was reluctant to sign the treaty and was in high grief. The Resident utilized the services of Queen mother again to get signatures on the treaty of annexation. He promised to arrange an annual stipend of one lakh rupees to the royal family in the name of Wajid Ali Shah, if she could manage to get signatures on the said treaty, which would be paid by the Company. ${ }^{64}$ She played an instrumental role, and no doubt, there was no other practical option to be followed.

It was again Queen mother who led the royal troupe to England to file a petition against the 'shameful occupation' 65 of their kingdom by the BEIC in place of Wajid Ali Shah. Maseeh-ud-Din Alvi was lawyer and ambassador of the exKing. ${ }^{66}$ Queen mother led the case in the British parliament and the court with the argument that Awadh was an unresisting ally and it was annexed without reasonable cause. ${ }^{67}$ They were hopeful of the decision in their favour, but selfish associates of Wajid Ali Shah convinced him to accept the offer of a high annual stipend from the Company in place of the state. He announced the withdrawal of the case from the court. ${ }^{68}$ Queen Kishwar was so upset with the decision that she died in Paris on her way back to India. One very significant but unheeded contribution of Queen Kishwar was her strong stand against declaring her a 'British subject.' ${ }^{69}$ She was asked by the British authorities in London to take a British passport, if she was interested to travel back to India via Mecca, but she rejected it altogether. She believed in her independent identity and was not ready to officially declare that Awadh was annexed..$^{70}$ This step of the Queen includes her name in the list of all those nationalists who resisted against the British occupation.

The last but not the least mighty character in the list of such royal ladies was Hazarat Mahal, ${ }^{71}$ mother of Prince Birjis Qadar, one of the wives of Wajid Ali Shah.72 She led the revolt in Lucknow. Birjis ascended the throne under supervision of her mother Hazarat Mahal. She was a brave leader and had a

64. Ibid, 150-151.

65. Wilberforce, Dacoity in Excelsis or the Spoliation of Oude, iii.

66. Maseeh-ud-Din Alvi, Safeer-e-Awadh (Lucknow: Dar un Nazir Press, n.d.), 93.

67. Wilberforce, Dacoity in Excelsis, iv.

68. Ibid, 99.

69. Simran Vijan, "Malika Kishwar (1803-1858): The Queen Who Ventured beyond the Zenana," Indian Women History (Jan 2020).

70. Ibid.

71. She belonged to a very poor family of slaves and was sold to the palace as royal attendant in very young age. She, however, managed to reach to the position of King Wajid Ali Shah's wife and mother of a prince due to her wit, intelligence and beauty. For details please consult: livehistoryindia.com/herstory/2019/04/12/begum-hazrat-mahal-arevolutionary-queen.

72. Munshi Ram Sahai, Ahsan ut Tawareekh (Lucknow: Tamanai Borum Chad, n.d.), 19; Hyder, Sawanehayat, 8. 
practical, good sense of leading the force. She extended respect to the soldiers but was helpless to lead the forces directly due to prevailing purdah tradition. ${ }^{73}$ She could rule for seven months only amid confusion and utter lawlessness. Her army was divided into many factions and all factions were fighting for their personal gains. A parallel court was also established under Ahmadullah, scholarsaint in Lucknow besides Hazarat Mahal. ${ }^{74}$ It further divided Lucknow society and forces into Shia and Sunni factions. This new kingdom was disintegrated within only two or three days once the bombardment was started by the British forces. ${ }^{75}$ Hazarat Mahal fled to Nepal with thousands of other fugitives. Only Hazarat Mahal and Birjis Qadar were given refuge by the state with a small amount of stipend. ${ }^{76}$ Awadh was re-occupied by the British completely in January 1858. ${ }^{77}$ Hazarat Mahal was one of the most prominent symbols of resistance among the list of royal women, who fought the game of 'do or die.' She led the resisting forces at the time when majority of the members of royal family including last King of Awadh were not in favour of fighting against the British. Her resistance was the longest against British usurpers among her contemporaries. $^{78}$ She did not make compromise with the prevailing circumstances and decided to rise in rebellion against the usurper.

This group of powerful royal women of Awadh had proven themselves as parallel partners of the state-machinery. On one side, Begum Sadar un Nisa, Bahu Begum and Queen Kishwar were fulfilling their duties of faithful associates of their counterparts in the game of politics and were successful in many cases. Then on the other side, Badshash Begum and Hazarat Mahal had tried to resist against the government and the BIEC. They were more courageous and audacious than many other male members of the royal family and had shown resistance in the difficult times.

\section{Institution of Courtesans/Tawaif}

The second cadre of influential women in Awadh can be named as courtesans, the most neglected section of women in the writings of history. This institution describes the life-style of Awadh. They were an influential female elite

73. Elite women's confinement to the female circles and surroundings was the tradition of the elites especially of the royal women and it was considered disrespectful for the women of royal families to come in the public without a veil or even with veil. They could talk to the males other than of their blood relations from behind the curtains.

74. Farqui Anjum Taban, "The Coming of the Revolt in Awadh: the Evidence of Urdu Newspaper," Social Scientist 26, no. 1/4 (1998): 18.

75. Sharar, The Last Days, 67.

76. Ibid, 76.

77. Sahai, Ahsan-ut-Tawareekh, 99.

78. Michael H. Fisher, The Multiple Meanings of 1857 for Indians in Britain. Retrieved from: http://www.csas.ed.ac.uk/mutiny/confpapers/Fisher-Paper. [Accessed 9 June 2021.] 
section of the society, not only in Awadh but also in all Hindu and Muslim courts of pre-colonial India. ${ }^{79}$ They, like many other courts of medieval India, were concerted with the Royal court and courtiers. They had influence and association with the royal family, nobility, merchants, courtiers, etc. They were highly active in urban areas. They manipulated men and means for their own social and political ends. ${ }^{80}$ They had deep influence on the male identity which was then distant away from the ideal of warriors of Mughal times. ${ }^{81}$

There was inner stratification of tawaifs also. This elite section was associated with the court or upper hierarchy. The other categories were thakahi and randi. They were ranked lower in stratification. ${ }^{82}$ The influence of this section of women was observed for the first time in Awadh during the time of Nawab Shuja ud Daulah, who was slave to his sexual needs. He always kept a group of tawaif with the royal caravan in case of travelling or even during military campaigns or sometimes, such women were locally arranged. His death had happened due to a knife-wound on his upper-leg, which was given by a noble girl, who mistakenly had been kidnapped for sexual pleasure of the king. The knife was poisoned and Nawab Shujja got sick after that event. ${ }^{83}$ The poison spread in his whole body and he died within few days. Nevertheless, the rise of courtesans had been started in the court of Awadh.

Nawab Asif ud Daula was kind towards dancing girls and gave heavy prizes to even common dancers. ${ }^{84}$ Mukhtar ud Daula, Prime Minister of Asif-ud Daula, was involved extremely in love of a tawaif, perhaps Jalalu. She was a clever and highly cultured lady. Mukhtar did what that lady wanted. She actually ruled in place of Mukhtar ud Daula. Mukhtar, on instigation of Jalalu had created misunderstandings between the King and the Queen mother, and later, convinced Asif ud Daula to take a heavy amount of money from Bahu Begum. Mukhtar, after getting approval from the King, led the campaign to Faizabad for exploring money. There were only eunuchs in the palace. Begum was reluctant but she had to give Rs. six million through the British Resident. Later, the Begum developed hatred for her son and started favouring other sons of Shuja ud Daula..$^{85}$

King Naseer ud Din Hyder lived so excessively in the company of such women that most of his styles had been transformed into womanish. He spoke

79. Lata Singh, "Visibility the 'Other' in History: Courtesans and the Revolt," Economic and Political Weekly 42, no. 19 (2007): 1678.

80. Veena Talwar Oldenburg, "Lifestyle as Resistance: The Case of the Courtesans of Lucknow," Feminist Studies 16, no. 2 (1990): 2.

81. Simonetta Casci, "Lucknow Nawabs: Architecture and Identity," Economic and Political Weekly 37, no. 36 (2002): 3711.

82. S. N. Singh, The Kingdom of Awadh: Its History, Polity and Administration (New Delhi: A Mital Publication, 2003), 30-31.

83. Ghani, Tarikh-i-Oudh, 145.

84. Najmul Ghani, Tarikh-i-Oudh, 26.

85. Ibid, 54-56. 
like women, sang like women, behaved like women and even dressed like women. This, combined with his religious ardour, "made him influenced to perform practically, while celebrating birth ceremony of Imam to play role of a pregnant woman." 86 King would take a bath and went to the city in palanquin in rich female costume. In December 1849, the King divorced one of his courtesan wives, Surfraz Mahal, and sent her to Mecca for pilgrimage. She had been cohabiting with the chief singer, Gholam Reza, and with some other royal men, even with the ministers. The king was highly dejected on finding it true. ${ }^{87}$ Moral degeneration was also part of the life of such wives.

The courtesans had become cause of sever conflicts among courtiers and respectable persons also. Two sons of Aga Meer, Minister of Ghazi ud Din Hyder, were kidnapped by Eesa Mian, a fake saint. He developed liaison with a dancing girl, Beeba Jan. The girl was not happy on furious attitude of Eesa Mian and took refuge with Khasmahal, the Chief consort of Aga Meer. He wanted the release of the girl. The issue was settled peacefully only with the involvement of the British Resident. Beeba Jan was released and in response to it, the two sons of the ministers were handed over to their parents. ${ }^{88}$

Overall, the courtesans were politically conscious and knew where to accept the commandments and where to reject and react. They were well connected with the local elites and had plenty of revenue since the 1780s. ${ }^{89}$ They whole heartedly supported the War of Independence in 1857,90 some of them even became part and parcel of the activities of the freedom-fighters. They were fearful of the shift of their position from high cadre courtesan to common prostitutes, ${ }^{91}$ so decided in favour of the revolt. Although they were not a respectable class in moral terminology, their resistance had value. This group gained much power in the later period of the dynasty and at most of the occasions, this group of women interfered indirectly, through the royal men with whom they had illicit relationships.

\section{Less Influential Royal Women}

There was a large group of royal women who were less influential due to their position in the court, but this group was comparatively more active than the first two groups. This group included sisters, daughters, wives other than the chief wife and other relatives. Shuja ud Doula had twenty-five daughters; only one was married, Izzat un Nisa Begum. All others did not want to marry due to

86. Sharar, Lucknow: the Last Phase, 57.

87. Sleeman, Rambles and Recollections, 46-47.

88. Ibid, 10-18.

89. Lata Singh, "The Visibilty of the 'Other'..", 1680.

90. Oldenburg, "Lifestyle as Resistance...", 3.

91. Kokila Dang, "Prostitution, Patron and the State: Nineteenth Century Awadh," Social Scientist 21, no. 9/11 (1993): 175. 
their inability to obey their husbands. They spent their lives like liberal men. Initially, they were paid Rs. 70 per month. Later, Nawab Sada'at Ali Khan raised the stipend to Rs. 250 as a monthly salary. All of them were discontented of less salary. They got reactionary and attacked a government's bungalow in Pitch Muhallah (street) while closing Shaikhan door and doors of Hasan Bhaagh (garden). They looted everything from the house while claiming that it was their father's property. Nawab increased their monthly salary to Rs. 500 per head. They were still dissatisfied and reminded Nawab Sada'at that they were like him. Nawab's attitude was polite towards them. During Ghazi ud Din Hyder's period, three sisters, Anjumannisa, Zaibunnisa and Jeena Begum went to Lord Myre, in Benaras, with the petition of less salary. He extended respect to them and said that he will settle the matter on his visit to Lucknow. Ghaziuddin increased their monthly stipend to Rs.700 per person. ${ }^{92}$

Shams un Nisa Begum, wife of Asif ud Daula, daughter of Nawab Intizam ud Daula and granddaughter of Nawab Qamar ud Din, Prime Minister of Mughal emperor in Delhi court, was one of the less active royal ladies. She did not have any child and could not develop cordial relations with her husband. Asif ud Daula left her in Faizabad while leaving the city and settled a new capital in Lucknow. ${ }^{93}$ She lived in Machli Bhawan and was given with the jagir of Partab Ganj and Nawab Ganj with Rs. 60000 annual income. In addition, Rs. 60 were fixed for her kitchen on daily basis. A small part of her jagir was taken over by the Nawab on which she got infuriated and went to live in her jagir. She could not revive relationship with her husband and died there after a few years. ${ }^{94}$

The royal ladies of this cadre were found to be involved in palace intrigues also. Queen mother Dowager, with the help of the King Amjad Ali Shah, used power against some wives of the King. The King was informed by the Queen mother, Dowager, that having a mark of 'Sampun" on the neck of any wife of the King could be harmful for his children. The King checked the mark with the help of the chief eunuch and discovered that eight of his wives had that mark. He immediately ordered them to leave the palace with all of their belongings and the ladies had to follow the orders. ${ }^{95}$ Chief wife of Wajid Ali Shah, Azam Bahu, daughter of Nawab Ali Khan Bahadur was another less powerful lady. She was fed up of the many love-affairs of her husband. She tried to successfully cater with those girls but later, she had to make compromises. ${ }^{96}$

This third category of royal women had some very active ladies besides less active. Some of them did not make any compromises, but others had to. This group of royal women was mostly active in the palace conspiracies or was

92. Qaisar ut Tawarikh, in Najmul Ghani, Tarikh-i-Oudh, 309-310.

93. Michael H. Fisher, "Political Marriage Alliances...," 603.

94. Hyder, Sawanehayat-Salateen, 81.

95. Sleeman, Rambles and Recollections, 107-108.

96. Ghani, Tarikh-i-Oudh Vol. V., 55. 
operating for their own financial benefits. Their share in political life of the state was less visible.

\section{The Employees of the Royal Household}

Some associated ladies like head cook, governess, etc. also got influence and power with some kings. Faiz un Nisha was the closest associate of Badshah Begum and the most trustworthy. She was foster mother of her son/heir apparent, Naseer ud Din. She even accompanied the Begum in many of her political and domestic designs including the murder of one of the wives of Ghazi ud Din i.e. Subh Daulat. ${ }^{97}$ Mir Fazal Ali, nephew of the same Faiz un Nisha was appointed as Naib (Prime Minister) of Naseer ud Din in 1827 on advice of Badshah Begum. ${ }^{98}$ She controlled the affairs of the State directly through Mir Fazal Ali. During Naseer ud Din's period, Barati Khanum (king called her duda) was in charge of the kitchen. King trusted her a lot; even some ministers also conveyed their wishes or requests to the King through her. The state affairs had reached the King through Barati Khanum. Two other ladies, Jugna Khanum and Naurozi Begum worked under Barati Khanum and were also very influential. This group of women was very rich and celebrated taziya $a^{99}$ and other Shia rituals with great pomp and show. ${ }^{100}$ Their influence reached to such a level that the Resident scolded Naseer ud Din and reminded him of the real status of the King. King thought that Naurizi Khanum had leaked out the news of the bad state of affairs so she was dismissed and sent out of the palace. ${ }^{101}$

It was unusual in the history of Indo-Pakistan subcontinent that female royal employees could enjoy this level of power and esteem, which they had earned in Awadh.

\section{Literary, Architecture, and Cultural Activities}

History of Awadh is unique in the sense of its cultural, literary and creative development. A lot of such works had been produced there which were exemplary. ${ }^{102}$ Persian and Urdu both flourished, and the contribution of women was equally visible in this regard also. Bahu Begum patronized the men of

97. Subh Daulat had given birth to the only male-child of Gazi ud Din i.e., Naseer ud Din Hyder.

98. Taqi, Tarikh-i-Badshah Begum, 5 and Sleeman, Rambles and Recollections, 272.

99. Tazia is a Shia ritual in which a replica of Hazrat Imam Hussain's (grandson of Holy Prophet (PBUH)) tomb is taken in form of a procession.

100. Ghani, Tarikh-i-Oudh, 337.

101. Ibid, 338.

102. Moeen ud Din Aqeel, Janubi Asia Ki Tarikh Naweesi, Noeeyat, Rawaiyat and Mayar (Lahore: Nashriyat, 2015), 83. 
literature and historians also. Faiz Bakhsh Kakori, author of Tarikh-i-Farah Bakhsh was an employee in the jagir of Bahu Begum. His book covers the period of Shuja ud Daula, Asif ud Daula and Sada'at Ali Khan. He had written a lot of eyewitness accounts. His book Shahma-i-Faiz was an autobiographical work as well as historical. He had access to such facts and files, where common a historian could not reach because he was a trustworthy employee of Bahu Begum. His third work was a social history of Awadh. In another work, he had written about land lords, friends, relatives, etc. who lived in Lucknow, Faizabad and other areas. ${ }^{103}$

Aqleel Mahal, one of the wives of Wajid Ali Shah, was named as Mumtaz Mahal by the last King of Awadh, also had literary taste. She was granddaughter of Shuja ud Daula and had a son, Qira Hussain Mirza. She did not accompany Wajid Ali Shah to Calcutta and was left behind in Lucknow. Wajid Ali Shah wrote a series of letters to her and wished that all his letters be compiled in the form of a book. Being a faithful wife, she collected all of the letters and got it published in the form of a book with the title of Tarikh-i-Mumtaz. ${ }^{104}$ The letters are of high literary taste and show a passionate relationship of husband and wife.

Women became directly the theme of poetry, produced in the state of Awadh, which was the first time in the history of the Muslim rule in India. Wajid Ali Shah had written such poetry in abundance in which he had mentioned his love affairs clearly with the indication of one or more women including courtesans, maids, passer-bys or others. ${ }^{105}$ Nawab Mirza Shauq, "in his poems became the lover of beautiful veiled women and made his poetry the 'scourge of conventional morality. ${ }^{\prime 106}$ The language of his masnavis ${ }^{107}$ was so beautiful, frank, pure and clean that even honorable and decent people could not abstain from reading and enjoying it. Wajid Ali Shah, on the contrary, had showed shamefully low taste and used obscene language.

The institution of courtesan meant to preserve the high culture of Lucknow. They were the real protectors of the cultural norms of Lucknow and practically shaped the development of modern music, dancing and singing. Lucknow court was a celebrated 'center of musical entertainment.'108 Women, especially courtesans, had great aesthetic sense. The other centers of India followed the styles, introduced by the courtesans of Awadh. ${ }^{109}$ Some of them, like Zohra and Mushtari, were not only poetesses but also were singers and dancers. Jaddan was

103. Ibid, 85 .

104. Mohammad Baqir, Tarikh-i-Mumtaz: Letters of Wajid Ali Shah to Aqleel Mahal (Lahore: Danish Gah-i-Punjab, 1952), 11.

105. Sharar, Lucknow: the Last Phase, 63.

106. Ibid, 63.

107. It is a genre of poetry, collection of anecdotes.

108. Jon Barlow and Lakshmi Subramanian, "Music and Society in North India: From the Mughals to the Mutiny," Economic and Political Weekly 42, no. 19 (2007): 1784. 109. Lata Singh, "Visibility the 'Other'..." 1678. 
another singer and dancer. ${ }^{110}$ They introduced music and dancing as a profession. Court of Wajid Ali Shah was immune to such performances on a daily basis. Drama also flourished during Wajid Ali Shah's period with active involvement of the skillful courtesans. ${ }^{111}$ One group of men and women were employed and trained, especially for the drama, Daryaye Ta'shque (Ocean of love), in the art of dancing and singing. They were taught a number of couplets to be recited in the appropriate places. With the start of the War of Independence, the development of music was stopped to a large extent. ${ }^{112}$

Begums of Awadh were also fond of constructing buildings, especially religious edifices and buildings for the welfare of their dependents. Begum Sadar un Nisa constructed an imam bara and a mosque behind Moti Baagh. Her dependents were very happy and satisfied. ${ }^{113}$ Bahu Begum laid the foundation of Nagariya and Ali Ganj, on the other side of the river. These were new colonies for her associated people. ${ }^{114}$ In the palace of Awadh, Badshah Begum had built twelve tombs for each of the twelve imams, besides a mosque, adjacent to every tomb. One building similar to the tomb of Hazrat Abbas was also constructed. ${ }^{115}$ The buildings constructed by the Begums were symbols of their power, religious inclination and high sense of social welfare besides fine taste.

Rulers of Awadh were practicing Shia faith with scrupulous care and regularity and adopted pure Shia rituals on the state level. The most prominent rituals were the holding of Majlis (mourning assembly), Soz Khawani (a special form of music i.e., sad songs) and taking out tazia processions. ${ }^{116}$ Sleeman had also mentioned the hectic schedules during the Islamic month of Moharram.117 Mourning of Moharram and taziyya was the most important aspect of royal women's lives in Awadh. Some innovations had also been introduced by the royal ladies especially Badshah Begum, including celebration of chhati ceremony of Imam Mehdi, celebrated every year in the month of Shaban and secondly, eleven beautiful Syed girls were declared as wives of eleven imams and were kept in the royal palace with high respect and status. ${ }^{118}$ Begum spent days and nights in prayer and worship. As Mirza Naseer -ud Din Hyder was brought up by Badshah Begum, so he was highly careful of these practices in his life. ${ }^{119}$

110. Sharar, Lucknow: the Last Phase, 145.

111. Syed Masood Hasan Rizvi, Adeeb and Ayesha Irfan, "The Royal Stage of Lucknow," Indian Literature 54, no. 5 (2010): 112.

112. Subramanian, "Music and Society in North India...," 1784.

113. Najmul Ghani, Tarikh-i-Oudh, 337.

114. Sharar, Lucknow: The Last Phase, 48.

115.Taqi Ahmad, Tarikh Badshah Begam, 9.

116. Sharar, The Lucknow: The Last Phase, 215.

117. W. H. Sleeman, Journey through the Kingdom of Oudh in 1849-1850 (Lucknow: Helicon Publications, 1989), 1.

118. Taqi Ahmed, Tarikh Badshah Begam, 9.

119. Ibid, $6,9$. 
Badshah Begum, with her religious innovations and involvement of the King and associates in the religious ceremonies, had controlled the cultural life of the court. ${ }^{120}$

Most of these rituals gradually were adopted by Shias of the other parts of India also. Courtesans also compelled themselves to sing 'religious songs of mourning ${ }^{\prime 121}$ during the days of Muharram. All other activities were banned and the days were spent in complete sorrow during that period.

The cultural norms and innovations of the royal women had a deep impact on common women also. Common women were fond of soz khuwani. Especially during days of Muharram, matchless sounds of dirges could be heard from every street and muhalla. ${ }^{122}$ Common women had a lot of occasions in their lives to celebrate. Most of the Muslim families had sufficient financial resources and the women could spend money on such occasions. Celebration of Chati, cutting of the hair of baby, aqiqa, ${ }^{123}$ bismillah $^{124}$ (at the age of four), start of the commencement of their education, circumcision, roza kushai, ${ }^{125}$ aqdi-i-Nikhah ${ }^{126}$ were common festivities among the women. ${ }^{127}$

The tradition of majlis, with inclusion of marsiya and soz khawani, had great impact on noble and common women of Awadh. Due to regular assemblies, taste for poetry and music had become part of noble women's life, which was specific to only this part of the Indian Muslim society. ${ }^{128}$ Soz khawani had given vitality to music especially to Urdu music.

\section{Financial Resources}

The financial resources and economic status of all groups of elite women affiliated with the court, varied from group to group. Begums of Awadh had plenty of wealth. Every Chief Wife was granted with jagirs or estates: extensive in size and rich in agricultural yield. They were all in all to manage the affairs of their jagirs and to utilize the resources. Begum Sadar un Nisa, Bahu Begum, Badshah Begum, etc. were even more financially sound than the Nawabs or Kings.

120. Manisha Choudhry, "Domesticity, Religion and Politics: Exploring Life in Royal Palace of Awadh," International Journal of Social Science Tomorrow 1, no. 4 (2012): 2.

121. Mushirul Hassan, "Traditional Rites and Contested Meanings: Sectarian Strife in Colonial Lucknow," Economic and Political Weekly 31, no. 9 (1996): 543.

122. Sharar, Lucknow: the Last Phase, 149.

123. Islamic ritual of animal sacrifice on the birth of the baby.

124. Ceremony related to the start of taking lessons of Muslims' Holy book i.e., Holy Quran.

125. This ceremony was celebrated on the opening of the first fast of the child.

126. Marriage ceremony.

127. Ibid, 203-205.

128. Ibid, 217. 
They came up with their own money on many occasions to help the Nawabs. Begum Sadar un Nisa controlled a big jagir and a substantial amount of money, which was spent on the state on the basis of need, besides the needs of the Begum and affiliated band of servants and other dependents. ${ }^{129}$ Bahu Begum was owner of the jagirs of Gonda and Faizabad during the life of Shuja, and later other jagirs were also given to her. Besides that, she was in charge of the royal treasury. The control of finances by Bahu Begum proved to be the major cause of conflict between her and her son, Nawab Asif ud Daula. Chief wife of Asif ud Daula was owner of the jagirs of Partab Ganj and Nawab Ganj with Rs. 60000 annual income. Nawab Saadat Ali Khan gave Nawab Ganj as jagir to his favorite wife, Tat Mahal. Its annual income was one lac twenty thousand. She had ownership of jewelry of one crore also. ${ }^{130}$

The finances of the Chief wives or the other wives were always given priority, even while signing treaties with the British. Article six of the treaty between Nawab Shuja ud Daula and the Company said that 2 lac out of 76 lacs revenue would be fixed for the stipend of the Begums and princesses of the royal family. ${ }^{131}$ Financial resources of some of the wives, with names, of the Kings was part and parcel of the loan agreements between the Company and the state. While taking third loan from Awadh, the Company agreed to pay back the loan with 5 percent interest. Additionally, the Company pledged to pay monthly allowances of Rs. 10,000 and 2500 respectively to Nawab Mubarak Mahal Sahib and Sultan Mariyam Begum, and the wives of Ghazi ud Din Hyder. ${ }^{132}$ Such large estates of lands and jewelry were later extracted by governor general Warren Hastings. ${ }^{133}$

These Begums were mostly very kind and gave a large part of their wealth in alms to the poor. Begum Sadar un Nisa was very generous and spent most of her time in prayer. A lot of poor were paid with the monthly stipend from her jagir's income. ${ }^{134}$ Bahu Begum had fixed stipends for many of her relatives and poor families on a monthly basis. Her nephews, Nawab Qasim Ali Khan, Asghar Ali Khan and Akbar Ali Khan, were paid Rs.1000 each. ${ }^{135}$ She was so careful about the livelihood of all of her dependents that she made arrangements with the help of the Resident to pay them monthly allowances even after her death.

The courtesans, the leading section of tawaif, also had a lot of financial resources. Although they were not paid with the fixed income and all were not allotted with the jagirs, they skillfully gathered a heavy amount of wealth. The

129. Details are given on the above pages.

130. Najmul Ghani, Tarikh-i-Oudh, 105.

131. Knowsley Pamphlet Collection, Oudh or How to Make and Unbreak a Treaty (Calcutta: J. F. Bella my Englishman Press, 1856), 12.

132. Mir Litvak, "A Failed Manipulation: The British, the Oudh and the Shi'I Ulma of Najuf and Karbala," British Journal of Middle Eastern Studies 27, no. 1 (2000): 70.

133. Veena Talwar Oldenburg, The Making of Colonial Lucknow, 1856 -1877, VI.

134. Najmul Ghani, Tarikh-i-Oudh, 226.

135. Hyder, Sawanehayat, 145. 
males of the royal family and the courtiers were in habit of visiting such women on payment of money, property and costly gifts to them extensively. Many of them were even granted big and luxurious homes to live in and to serve the specific people. They were the highest taxpayers with the heaviest incomeearners and property-holders. ${ }^{136}$ The British authorities, after annexing Awadh, were astonished to study the tax records and financial files which were clear indications of wealthy status of the courtesans.

The third group of women, however, was not financially sound. They even had to show resistance and had to fight for the increase in their monthly income on various occasions. Wives, khurd mahals, sisters, daughters, all were paid with the monthly income. ${ }^{137}$ Each Sahib-i-Mahal was given Rs. 5000 since the time of Naseer-ud-Din Hyder. ${ }^{138}$ There were few female employees of the royal household including Barati Khanum and Naurozi Khanum who could collect money extensively.

\section{Conclusion}

Awadh, a Shia state, was comparatively more liberal than many Sunni states of India in the period of resistance against foreign powers. Royal women, especially of the first group i.e., Begums of Awadh, had enjoyed high status since the beginning, which further increased with the passage of time. One of the reasons could be that state was inherited to son-in-law of its founding father, and as Sadr un Nisa Begum was daughter of an ex-Nawab, wife of the second Nawab and mother of the third Nawab, her power and esteem was countless even during the period of Shujja ud Daula. She directly interfered to settle some issues related to the Hindu Rajput family being Queen mother. Her views, commandments and even financial resources were part and parcel to the policy-making and the state structure since the establishment of the state. The ministers of the state listened to her and obeyed her. She practically set the trend for future royal ladies who did not face as much difficulty to get acknowledgement from their male counterparts to be politically active. Bahu Begum was equally powerful during a long period to come because she was given high esteem by her husband, Shuja ud Daulah. She had complete authority of the royal treasury and was owner of an enormous estate. She was one step away than Begum Sadar un Nisa as she was on very cordial terms with the BEIC also through its resident. The Company's officials had also accepted her power. Badshah Begum was comparatively a different case. She led a coup against the sitting King and the Company which took her to the height of resistance. She set a great example of resistance. Another royal woman

136. Oldenburg, "Lifestyle as Resistance...," 1.

137. Najmul Ghani, Tarikh-i-Oudh, 5.

138. Sahai, Ahsan-ut-Tawareekh, 124. 
who proved to be more courageous and dynamic was Hazarat Mahal. She can be quoted as the best model or symbol of resistance against the colonial power. She fought a war of do or die. Many courtesans were also supporting that difficult war for their personal interests, or regaining their past glory of ruling indirectly while having closer links with the royal family and other courtiers. Courtesans' political power, though indirect, is also undeniable. They were behind many court skirmishes and intrigues and the men of the royal family listened and followed them. That glory of the courtesans could never be revived.

Besides politics, the Awadhian women were not behind men in bringing revolution in multiple fields of literature and art including poetry, music, singing, dancing and drama, etc. Begums of Awadh appointed historians and literary figures in their jagirs and promoted education. However, the role of courtesans in elevation of various domains of art is irrefutable. It was due to them that music, dancing, singing and even drama was promoted and performing in all these fields was recognized as a profession. These fields of earning money were then not looked down upon. They introduced the concept of respecting the workers of this profession; however, on limited scale. Furthermore, elite women were also fond of constructing buildings like their men and some masterpieces, especially religious buildings, were constructed by them. In the later period, space for women had been created by royal men who were involved in merrymaking, wine, women and other unproductive works. The status and role of royal ladies of Awadh in politics, economic matters, promotion of art, literature and architecture, etc. is definite, which needs recognition and appreciation.

\section{Bibliography}

Ahmad, Muhammad Taqi. Tarikh Badshah Begam. (History of Badshah Begum). Allahabad: K. Mitra, 1938.

Alvi, Maseeh-ud-Din. Safeer-e-Awadh. Lucknow: Dar un Nazir Press, n.d.

Aqeel, Moeen ud Din. Janubi Asia Ki Tarikh Naweesi, Noeeyat, Rawaiyat and Mayar. (Historiography of South Asia: Style, Tradition and Standard). Lahore: Nashriyat, 2015.

Baqir, Mohammad. Tarikh-i-Mumtaz. (History of Mumtaz). Lahore: Urdu Markaz, n.d. . Tarikh-i-Mumtaz: Letters of Wajid Ali Shah to Agleel Mahal. Lahore: Danish Gah-iPunjab, 1952.

Barlow, Jon and Subramanian, Lakshami. "Music and Society in North India: From the Mughals to the Mutiny." Economic and Political Weekly 42, no. 19 (2007): 1779-1787.

Basu, Purnendu. Oudh and the East India Company, 1785-1801. Lucknow: Maxwell Company, 1943.

Bhatnagar, G. D. Awadh Under Wajid Ali Shah. Varanasi: Bharatiya Vidya Prakashan, 1965.

Casci, Simonetta. "Lucknow Nawabs: Architecture and Identity." Economic and Political Weekly 37, no. 36 (2002): 3711-3714.

Chancey, Karen. "Rethinking the Reign of Asaf ud Daula, Nawab of Awadh, 1775-1797." Journal of Asian History 41, no. 1 (2007): 1-56. 
Vol. 7, No.4 Kiran: Stratification and Role of the Elite Muslim Women in the State...

Choudhry, Manisha. "Domesticity, Religion and Politics: Exploring Life in Royal Palace of Awadh." International Journal of Social Science Tomorrow 1, no. 4 (2012): 1-14.

Dang, Kokila. "Prostitution, Patron and the State: Nineteenth Century Awadh." Social Scientist 21, no. 9/11 (1993): 173-196.

Fisher, Michael H. "The Imperial Coronation of 1829: Awadh, the British and the Mughal." Modern Asian Studies 19, no. 2 (1985).

. The Multiple Meanings of 1857 for Indians in Britain. Retrieved from: http://www.csas. ed.ac.uk/mutiny/confpapers/Fisher-Paper. [Accessed 9 June 2021]

. "Political Marriage Alliances at the Shi'i Courte of Awadh." Comparative Studies in Society and History 25, no. 4 (1983): 593-616.

Ghani, Maulana Mohammad Najam ul. Tarikh-i-Oudh. (History of Oudh), volume I. Udipur: np, 1910.

. Tarikh-i-Oudh. (History of Oudh), volume II. Udipur: np, 1910.

Hassan, Mushirul. "Traditional Rites and Contested Meanings: Sectarian Strife in Colonial Lucknow." Economic and Political Weekly 31, no. 9 (1996).

Hyder, Syed Kamal ud Din. Swanehayat-Salateen Awadh. (Biographical Accounts of the Sultans of Awadh), volume I. Lucknow: Valashkor, 1879.

Khan, Nawab Husayn Ali. "Tarikh-i-Husayniyyah." In Perspectives on Mughal India: Rulers, Historians, Ulama and Sufis, edited by Sajida Sultana Alvi. Karachi: OUP, 2012.

Knowsley Pamphlet Collection. Oudh or How to Make and Unbreak a Treaty. Calcutta: J. F. Bella my Englishman Press, 1856.

Litvak, Mir. "A Failed Manipulation: The British, the Oudh and the Shi'I Ulma of Najuf and Karbala." British Journal of Middle Eastern Studies 27, No. 1 (2000).

Oldenberg, Veena Talwar. "Lifestyle as Resistance: The Case of the Courtesans of Lucknow." Feminist Studies 16, no. 2 (1990): 259-287. . The Making of Colonial Lucknow. Delhi: OUP, 1989.

Peters, Julie Stone. "Theatricality, Legalism and the Scenography of Sufferings: The Trial of Warren Hastings and Richard Brinsley Sheridan Pizarro." Law and Literature 18, no. 1 (2006): 15-45.

Rizvi, Syed Masood Hasan Adeeb and Irfan Ayesha. "The Royal Stage of Lucknow." Indian Literature 54, no. 5 (2010): 170-186.

Sahai, Munshi Ram. Ahsan-ut Tawareekh: Tarikh-i- Subah Oudh. (The Best of the Histories: History of the Province of Oudh). np: Munshi Puran Chand, n.d.

Sharar, Abdul Haleem. Hindustan Mein Mashriqi Tamadun Ka Akhri Namoona. (The Last Phase of an Oriental Culture in India). Lahore: Merkantil Press, n.d.

Sharar, Abdul Haleem. The Lucknow: The Last Phase of an Oriental Culture. Edited and Translated by E. S. Harcourt and Fakhir Hussain. New Delhi: OUP, 2001.

Singh, Lata. "Visibility of the 'Other' in History: Courtesans and the Revolt." Economic and Political Weekly 42, no. 19 (2007): 1674-1981.

Singh, S. N. The Kingdom of Awadh: Its History, Polity and Administration. New Delhi: Mittal Publications, 2003.

Sleeman, W. H. Journey through the Kingdom of Oudh in 1849-1850 Vol. 1. Lucknow: Helicon Publications1989, reprint.

Rambles and Recollections of an Indian Official, volume II. Revised by Vincent A. Smith. Karachi: OUP, 1973 (reprint).

Srivastava, Ashirbadi Lal. The First Two Nawabs of Oudh. Lucknow: The Upper India Publishing House Ltd, 1933. 
Taban, Farqui Anjum. "The Coming of the Revolt in Awadh: the Evidence of Urdu Newspaper." Social Scientist 26, no. 1/4 (1998).

Vijan, Simran. "Malika Kishwar (1803-1858): The Queen Who Ventured beyond the Zenana." Indian Women History (Jan 2020).

Wilberforce, Robert. Dacoity in Excelsis or the Spoliation of Oude by the East India Company: Faithfully Recounted with Notes and Documentary Illustrations. London: J. R. Taylor, 1954. 
